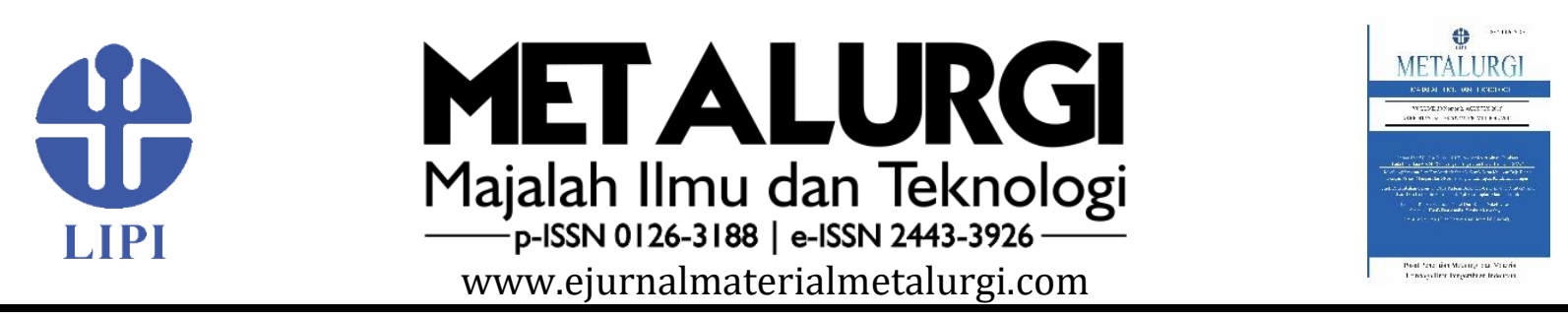

\title{
Pengaruh Penempaan dan Perlakuan Panas Terhadap Sifat MEKANIK DAN KETAHANAN KOROSI PADA MODIFIKASI BAJA LATERIT A-588
}

\author{
Miftakhur Rohmah*, Dedi Irawan, Toni Bambang Romijarso \\ Pusat Penelitian Metalurgi dan Material-LIPI \\ Gedung 470, Kawasan Puspiptek, Tangerang Selatan, Indonesia 15343 \\ *E-mail: Miftakhur.rohmah@lipi.go.id
}

Masuk tanggal : 22-02-2021, revisi tanggal : 16-04-2021, diterima untuk diterbitkan tanggal 30-04-2021

\begin{abstract}
Abstrak
Baja paduan rendah berkekuatan tinggi yang diaplikasikan menjadi baja tahan cuaca merupakan terobosan terbaru untuk menghasilkan sifat mekanik dan ketahanan korosi yang tinggi. Modifikasi baja laterit dengan penambahan kadar nikel yang diterapkan proses termomekanikal terkontrol (TMCP) berupa kombinasi proses penempaan panas dan perlakuan panas menjadi fokus penelitian ini. Sampel yang digunakan merupakan baja laterit A-588 hasil investment casting yang ditambahkan 1,2, dan $3 \%$ berat nikel, kemudian diproses penempaan panas dengan pembebanan 100 ton pada temperatur $1050{ }^{\circ} \mathrm{C}$. Nikel berfungsi sebagai penstabil austenit. Variabel perlakuan panas yang digunakan yakni (1) langsung pendinginan udara, (2) dilanjutkan proses pemanasan pada temperatur $750{ }^{\circ} \mathrm{C}$ yang diikuti pendinginan cepat. Karakterisasi material menggunakan uji metalografi, uji keras, uji tarik, dan uji polarisasi. Pada hasil tempa panas+pendinginan udara, pertambahan kadar nikel hingga $3 \%$ massa mempengaruhi nilai fraksi fasa ferrit-perlit yang terbentuk, pertambahan ukuran butir hingga $\pm 0,1 \mathrm{~mm}$, penurunan kekerasan hingga 185,22 BHN, penurunan kekuatan hingga $554 \mathrm{MPa}$, dan pertambahan regangan sebesar 29,1\%. Sedangkan pada hasil tempa panas+perlakuan panas dengan pendinginan air, pertambahan nikel hingga $3 \%$ massa menyebabkan terbentuknya fasa bilah martensit + ferrit + austenit sisa, penurunan kekerasan hingga 236,18 BHN, penurunan kekuatan hingga $852 \mathrm{MPa}$, penurunan regangan hingga 24,7\%. Fasa austenit sisa (retained austenite) memiliki efek merusak pada sifat mekanis.
\end{abstract}

Kata Kunci: Baja laterit A-588, austenit sisa, modifikasi baja laterit, tempa panas

\begin{abstract}
The application of HSLA (high-strength low alloy) for weathering steels is the newest innovation to produce high mechanical and corrosion resistance properties. Modification of laterite steel by nickel addition with a TMCP (thermomechanical control process) in the form of a combination of hot forging and heat treatment processes is the focus of this study, in which a nickel acts as an austenite stabilizer. The sample used was A-588 Lateritic Steel, resulting from investment casting, which has added nickel content of 1, 2, and 3\%, then processed by hot forging with 100 tons loading at $1050{ }^{\circ} \mathrm{C}$. Heat treatment variables used were (1) direct air cooling and (2) followed by a heating process at a temperature of $750{ }^{\circ} \mathrm{C}$ followed by a rapid cooling process. Material characterization was using a metallographic test, hardness test, tensile test, and polarization test. In hot forging + air cooling samples, the increase in nickel content up to 3 \% mass affects the value of the ferrite-pearlite phase fraction formed, the increase in grain size up to $\pm 0,1 \mathrm{~mm}$, the decrease in hardness is up to $185.22 \mathrm{BHN}$, the decline in strength is up to $554 \mathrm{MPa}$, and the elongation increase is $29.1 \%$. Whereas in the hot forging sample + heat treatment with water cooling, the rise in nickel up to $3 \%$ mass causes the formation of martensite + ferrite + retained austenite lath phase, a decrease in hardness to $236.18 \mathrm{BHN}$, a reduction in strength to $852 \mathrm{MPa}$, a decrease in elongation up to 24.7\%. The retained austenite phase has a detrimental effect on mechanical properties.
\end{abstract}

Keywords: A-588 lateritic steel, retained austenite, lateritic steel modification, hot forging

\section{Pendahuluan}

Material baja tahan cuaca untuk aplikasi infrastruktur khususnya struktur rangka jembatan di Indonesia menjadi salah satu fokus penelitian untuk meningkatkan sifat mekanik dan sifat ketahanan korosi atmosferik dari baja paduan 
rendah-berkekuatan tinggi (high strength low alloy / HSLA). Sayangnya, kedua sifat ini sering berbanding terbalik, dengan satu peningkatan dengan mengorbankan sifat lainnya. Dengan sifat "self protection" yang membentuk lapisan pelindung patina, baja tersebut dapat melindungi dari serangan korosi ketika terpapar dengan lingkungan atmosferik. Material baja tahan cuaca biasanya tidak memerlukan bentuk pemeliharaan apapun seperti pengecatan dan proteksi katodik, sehingga dapat dijadikan material alternatif yang sangat hemat biaya, jika dibandingkan dengan baja struktural lainnya. Umumnya, material baja tahan cuaca didominasi oleh baja paduan kromium-tembaga dengan penambahan unsur pemadu Ni, P, Mn, Si dan lain-lain yang total kadarnya tidak kurang dari 3-5\%, seperti pada material ASTM A-242, A-588, A-606, A-709, A852, A-871 [1]-[2]. Karakteristik lapisan pelindung patina yang stabil dipengaruhi oleh: (a) komposisi kimia seperti $\mathrm{Al}$ dan $\mathrm{Si}$, (b) pemrosesan baja, berkaitan dengan struktur mikro dan kehalusan butir, (c) kondisi lingkungan, (d) waktu pemaparan, (e) desain struktur [1],[3]-[5].

Konsep pengembangan baja tahan cuaca dengan meningkatkan kadar nikel hingga 3\% telah dilakukan beberapa waktu lalu [4]. Namun, kadar Ni yang tinggi akan meningkatkan biaya pembuatan baja. Oleh karena itu, diperlukan upaya pengembangan baja tahan cuaca yang berasal dari baja laterit Indonesia yang memiliki kandungan nikel antara 2-3\% setelah melewati proses converting dan metalurgi sekunder lainnya. Baja laterit memiliki kekuatan dan kekerasan tinggi dengan maksimum nikel 3\%. Adanya kandungan nikel hingga 3\% diharapkan dapat menggantikan penambahan ferronikel sehingga mengurangi biaya produksi.

Nikel berpeluang untuk menggantikan peranan krom pada paduan, sebagai penstabil austenit, meningkatkan ketangguhan, keuletan, dan ketahanan korosi. Y. Zhou, dkk. [6], dan X. Cheng, dkk. menyimpulkan bahwa nilai ketahanan korosi meningkat seiring dengan pertambahan nikel, namun mencapai batas efisien pada $3,5 \%$ Ni. Nikel mempengaruhi pembentukan lapisan protektif yang kompak, meningkatkan laju nukleasi $\mathrm{Fe}(\mathrm{O}, \mathrm{OH})_{6}$ jaringan nano, serta menghalangi pembentukan $\mathrm{Fe}_{2} \mathrm{NiO}_{4}$ yang tidak menguntungkan [7].

Baja hasil pengecoran memiliki cacat berupa porositas dan inklusi yang mengakibatkan sifat mekanis rendah sehingga diperlukan upaya untuk meningkatkannya dengan kombinasi perlakuan panas dan penempaan. Pada penelitian terdahulu, baja dengan perlakuan termomekanikal (pengerolan) yang menghasilkan struktur mikro ferrit-perlit atau bainit adalah pola utama untuk menghasilkan sifat mekanik dan ketahanan korosi atmosferik yang luar biasa tinggi [4]. Selain itu, proses perlakuan panas dan pembentukan logam dapat merekayasa struktur mikro sesuai yang diharapkan. Proses tempa menghasilkan aliran butir pada struktur mikronya, sehinga hasil produk akhir memiliki integritas struktural yaitu tanpa adanya kekosongan internal (void) dan porositas, serta memiliki sifat mekanik yang seragam. Oleh karena itu, penelitian ini secara khusus bertujuan untuk mengetahui pengaruh proses penempaan panas (hot forging) yang dilanjutkan proses perlakuan panas terhadap sifat mekanik dan ketahanan korosi pada material baja laterit, khususnya modifikasi paduan A-588. Material A-588 merupakan salah satu HSLA yang diaplikasikan menjadi baja tahan cuaca.

\section{Prosedur Percobaan}

Material awal yang digunakan dalam penelitian ini adalah baja laterit hasil pengecoran yang dibuat oleh Pusat Penelitian Metalurgi dan Material LIPI dengan komposisi utama mengacu pada standard ASTM A 588. Baja laterit merupakan baja yang diperoleh dari proses pemurnian dan peleburan ulang NPI (nickel pig iron). Untuk mengetahui pengaruh kadar nikel dalam baja laterit, modifikasi paduan dilakukan dengan cara perubahan komposisi kimia, yakni dengan menambahkan 1,2, dan $3 \%$ berat nikel ke dalam paduan utama, sehingga diperoleh komposisi kimia seperti pada Tabel 1. Paduan yang terbentuk tanpa mengandung unsur vanadium dan silikon jika dibandingkan dengan ASTM A-588.

Tabel 1. Komposisi kimia dari baja laterit A-588 - hasil pengecoran (\%berat)

\begin{tabular}{|c|c|c|c|c|}
\hline \multirow{2}{*}{$\begin{array}{c}\text { Komposisi } \\
\text { Kimia } \\
\text { (\%berat) }\end{array}$} & \multicolumn{4}{|c|}{ Modifikasi Baja Laterit } \\
\hline & MBL\#1 & MBL\#2 & MBL\#3 & MBL\#4 \\
\hline $\mathrm{C}$ & 0,16 & 0,15 & 0,14 & 0,13 \\
\hline $\mathrm{Mn}$ & 0,74 & 0,67 & 0,56 & 0,48 \\
\hline $\mathrm{P}$ & 0,01 & 0,01 & 0,01 & 0,01 \\
\hline $\mathrm{Si}$ & 0,12 & 0,07 & - & - \\
\hline $\mathrm{Ni}$ & 0,42 & 0,98 & 1,96 & 3,29 \\
\hline $\mathrm{Cr}$ & 0,62 & 0,63 & 0,61 & 0,59 \\
\hline $\mathrm{Cu}$ & 0,33 & 0,34 & 0,21 & 0,20 \\
\hline $\mathrm{V}$ & - & - & - & - \\
\hline $\mathrm{S}$ & 0,01 & 0,01 & 0,01 & 0,01 \\
\hline
\end{tabular}

Variabel pada penelitian ini adalah perbedaan kandungan kadar nikel dan perbedaan perlakuan panas pada modifikasi baja laterit, yakni 0,42 \%berat nikel (kode sampel MBL\#1); $1 \%$ berat nikel (kode sampel MBL\#2); 2 \% berat nikel (kode sampel MBL\#3); dan 3 \% berat nikel 
(kode sampel MBL\#4) dari berat total. Secara umum, komposisi kimia baja laterit termodifikasi sesuai dengan ASTM A-588 Grade K. ASTM A588 komersil mengandung 0,17 \% berat karbon (maks), 0,50-1,20 \%berat mangan, 0,04 \%berat fosfor (maks), 0,05 \%berat sulfur (maks), 0,4 \%berat nikel (maks), 0,40-0,7 \%berat krom, 0,1 \%berat molibdenum (maks), dan 0,30$0,50 \%$ berat tembaga [8]. Oleh karena itu, kadar unsur lainnya dianggap homogen dan tidak mempengaruhi secara signifikan karena masih dalam standar paduan A-588.

Paduan hasil pengecoran dipotong sebesar 10x1x1 cm sebanyak 2 buah. Selanjutnya, material tersebut dijadikan bahan baku pada proses tempa panas dan dilanjutkan perlakuan panas dengan diagram proses seperti diilustrasikan pada Gambar 1. Semua komposisi dipanaskan hingga temperatur austenisasi $1050{ }^{\circ} \mathrm{C}$ selama 30 menit didalam muffle furnace (kecepatan pemanasan $5{ }^{\circ} \mathrm{C} /$ menit), dan dilanjutkan dengan proses tempa panas (hot forging - single punch).

Proses penempaan dilakukan dengan menggunakan mesin Liyaoyang Metal Forming Tipe J53 dengan beban tempa sebesar 100 ton pada udara ruangan (open die forging). Selanjutnya, masing-masing sampel dilakukan variasi perlakuan panas, yakni (A) pendinginan udara / normalizing, dan (B) proses rekristalisasi dengan melakukan pemanasan ulang pada $750{ }^{\circ} \mathrm{C}$ selama 30 menit dan dilanjutkan dengan pendinginan cepat menggunakan media air (quenching). Proses penempaan-dua siklus menghasilkan reduksi ketebalan sebesar 38,84\%.

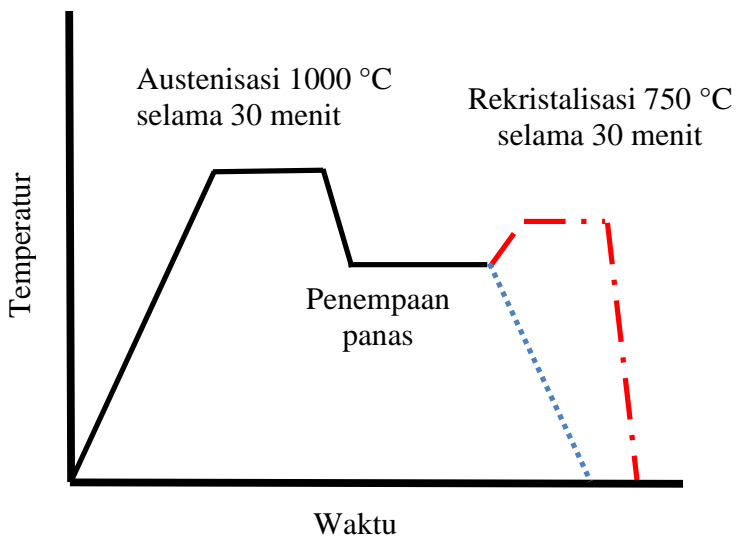

Gambar 1. Mekanisme proses penempaan dan perlakuan panas pada modifikasi baja laterit A-588

Baja laterit hasil tempa dan perlakuan panas kemudian dilakukan karakterisasi sifat mekanik melalui pengujian tarik, kekerasan, metalografi, serta karakterisasi sifat korosi melalui pengujian polarisasi. Pengujian kekerasan menggunakan metode Brinell (merk Mitutoyo HM-200) dengan beban identasi $1000 \mathrm{kgf}$ selama 10 detik.

Pada pengujian metalografi, sampel uji dipreparasi menjadi ukuran $1 \times 1 \times 1 \mathrm{~cm}$, kemudian dimounting dengan resin, diamplas, dipoles, dan dietsa menggunakan larutan pikral. Proses pengampelasan menggunakan kertas ampelas mulai kekasaran grade 80 - 2000. Sedangkan, proses pemolesan menggunakan pasta alumina dengan kekasaran $5-0,1 \mu \mathrm{m}$. Pada pengujian tarik, sampel uji dipreparasi mengacu pada standar ASTM E8.

Pengujian polarisasi dilakukan untuk mengetahui karakteristik sampel dengan media korosif berupa larutan $\mathrm{NaCl} 3,5$ \% volume pada temperatur kamar. Pengujian ini dilakukan dengan menggunakan tiga elektroda yaitu elektrode kalomel jenuh (SCE) sebagai elektroda referensi, platina sebagai elektroda pembantu, dan sampel sebagai elektroda kerja. Sampel dicelupkan selama 1 jam sebelum memulai uji polarisasi. Uji polarisasi dilakukan pada rentang potensial $-200 \mathrm{mV}$ sampai $+200 \mathrm{mV}$ dengan kecepatan scan $1 \mathrm{mV} / \mathrm{s}$.

\section{Hasil dan Pembahasan}

\subsection{Pengamatan Struktur Mikro}

Pengamatan struktur mikro dilakukan untuk mengetahui fasa akhir pada modifikasi baja laterit A-588 sehingga dapat diprediksikan transformasi fasa yang terjadi selama proses penempaan dan perlakuan panas. Pengamatan dilakukan dengan perbesaran 500x $(20 \mu \mathrm{m})$ dengan etsa pikral. Struktur mikro baja laterit setelah proses penempaan dan perlakuan panas ditunjukkan pada Gambar 2.

Gambar 2 menunjukkan struktur mikro pada modifikasi baja laterit A-588 dengan proses tempa dan perlakuan panas yang dilanjutkan dengan pendinginan udara terbuka (normalizing). Pada gambar tersebut, secara umum, struktur mikro yang terbentuk setelah proses A menjadi ferit (warna terang), perlit (warna gelap), dan karbida yang tersebar dalam struktur ferit. Struktur mikro as-cast setelah tempa panas menghasilkan butiran ferit berbentuk kolom halus yang cenderung memanjang (Gambar 2(a)). Seiring dengan penambahan kadar nikel, butiran ferit menjadi agak kasar seperti pulau tidak beraturan (Gambar 2(b)-2(d)). Pengasaran butiran adalah fenomena yang terjadi selama proses termomekanik seperti tempa panas [9]. Ukuran butir (micro grain size number $\mathrm{G}$ ) dapat ditentukan menggunakan metode Intercept (Heyne) sesuai ASTM E112. Variasi penambahan kadar nikel pada penelitian ini berpengaruh terhadap nilai fraksi fasa ferit-perlit 
yang terbentuk dan ukuran butir. Peningkatan kadar nikel akan meningkatkan fraksi perlit dan ukuran butir, seperti ditunjukkan pada Tabel 2 . Selain itu, modifikasi baja laterit A-588 dengan kondisi tempa panas ternyata memiliki beberapa porositas yang disebabkan oleh kualitas produk hasil cor.

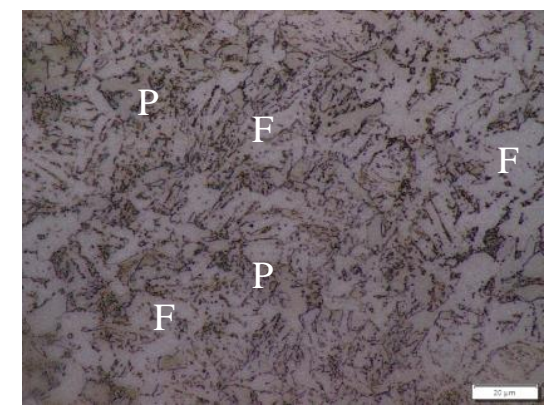

(a)

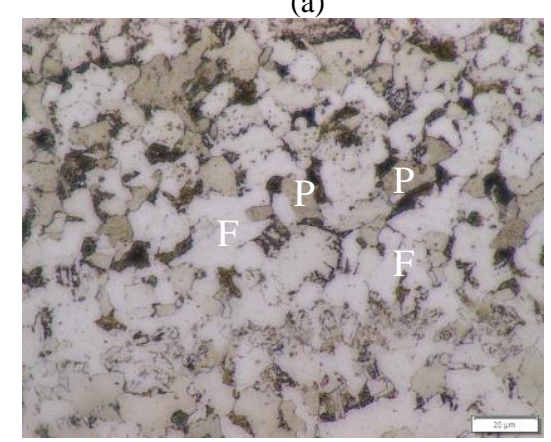

(b)

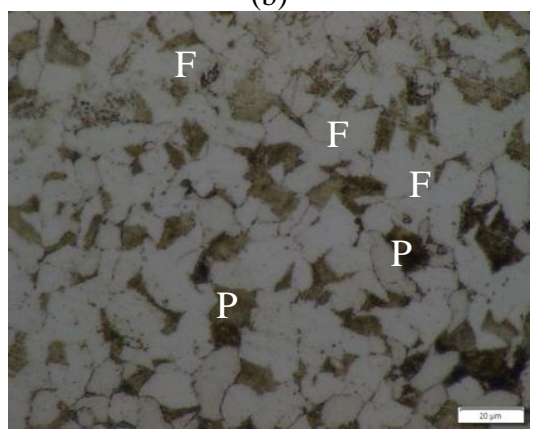

(c)

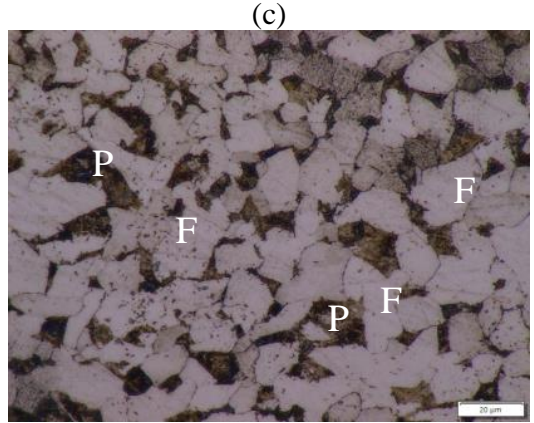

(d)

Gambar 2. Struktur mikro pada modifikasi baja laterit A-588 (a) 0,42 , (b) 1, (c) 2, dan (d) $3 \%$ berat nikel setelah proses penempaan yang dilanjutkan dengan pendinginan udara terbuka (normalizing) - etsa pikral ( $\mathrm{F}=$ ferit dan $\mathrm{P}=$ perlit). Etsa Pikral

Peningkatan ukuran butir pada penelitian ini sesuai dengan analisis ukuran butir Uddeholm Nimax, yang menyatakan bahwa prediksi ukuran butir untuk baja paduan rendah secara empiris dipengaruhi oleh temperatur pemanasan, waktu pemanasan, serta persen berat unsur $\mathrm{Ni}, \mathrm{Cr}, \mathrm{Mo}$, dan C [10]. Pada saat baja laterit dipanaskan hingga temperatur austenisasi (melewati garis $\mathrm{A}_{1}$ ), ferit dan perlit terlarut membentuk nukleasi dan pertumbuhan fasa austenit awal. Adanya penstabil austenit seperti nikel memungkinkan pembentukan austenit lebih banyak dan mendorong pertumbuhan butir yang cepat sehingga butiran semakin halus. Pada saat tempa panas, rekristalisasi butiran austenit dan transformasi fasa terjadi bersamaan dengan adanya deformasi sehingga ukuran butir austenit menjadi semakin besar dan kasar. Seiring pendinginan udara terbuka selama proses penempaan, sulit untuk mengkristalkan kembali austenit yang mengalami deformasi karena nukleasi yang tertunda menghambat proses dinamik rekristalisasi, sehingga fasa austenit cenderung bertransformasi menjadi ferit dan perlit [9],[11].

Peningkatan ukuran butir pada penelitian ini sesuai dengan analisis ukuran butir Uddeholm Nimax, yang menyatakan bahwa prediksi ukuran butir untuk baja paduan rendah secara empiris dipengaruhi oleh temperatur pemanasan, waktu pemanasan, serta persen berat unsur $\mathrm{Ni}, \mathrm{Cr}, \mathrm{Mo}$, dan C [10]. Pada saat baja laterit dipanaskan hingga temperatur austenisasi (melewati garis $\mathrm{A}_{1}$ ), ferit dan perlit terlarut membentuk nukleasi dan pertumbuhan fasa austenit awal. Adanya penstabil austenit seperti nikel memungkinkan pembentukan austenit lebih banyak dan mendorong pertumbuhan butir yang cepat sehingga butiran semakin halus. Pada saat tempa panas, rekristalisasi butiran austenit dan transformasi fasa terjadi bersamaan dengan adanya deformasi sehingga ukuran butir austenit menjadi semakin besar dan kasar. Seiring pendinginan udara terbuka selama proses penempaan, sulit untuk mengkristalkan kembali austenit yang mengalami deformasi karena nukleasi yang tertunda menghambat proses dinamik rekristalisasi, sehingga fasa austenit cenderung bertransformasi menjadi ferit dan perlit [9],[11].

Tabel 2. Nilai fraksi fasa dan ukuran butir dengan bantuan aplikasi ImageJ pada modifikasi baja laterit A-588

\begin{tabular}{ccccc}
\hline \multirow{2}{*}{ Material } & \multicolumn{2}{c}{ Fraksi fasa (\%vol.) } & \multicolumn{2}{c}{ Ukuran butir } \\
\cline { 2 - 5 } & Ferrit & Perlit & $\boldsymbol{\mu m}$ & No. G \\
\hline MBL \#1 & 76,96 & 23,04 & $\pm 55 \mu \mathrm{m}$ & 5,5 \\
MBL \#2 & 75,71 & 24,29 & $\pm 75 \mu \mathrm{m}$ & 4,5 \\
MBL \#3 & 75,15 & 24,85 & $\pm 90 \mu \mathrm{m}$ & 4 \\
MBL \#4 & 72,63 & 27,37 & $\pm 0,1 \mathrm{~mm}$ & 3,7 \\
\hline
\end{tabular}

Struktur mikro pada modifikasi baja laterit A588 setelah proses tempa panas dan perlakuan panas dengan pendinginan air ditunjukkan pada 
Gambar 3. Semua Gambar 3(a)-3(d) menunjukkan mikrostruktur multifasa yang meliputi bilah martensit, ferit, dan austenit sisa dengan distribusi homogen. Austenit sisa (retained austenite-RA) diindikasikan seperti blok tidak beraturan berwarna terang dengan batas butir kabur. Pemanasan pada temperatur $750{ }^{\circ} \mathrm{C}$ merupakan pemanasan interkritikal yang mengubah fasa perlit $\left(\alpha+\mathrm{Fe}_{3} \mathrm{C}\right)$ stabil di temperatur ruang (proses A) menjadi fasa austenit $(\gamma)$.

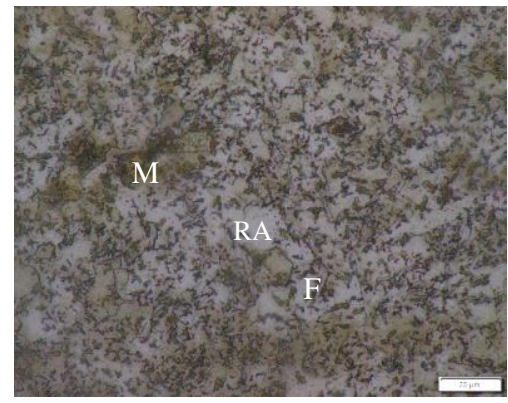

(a)

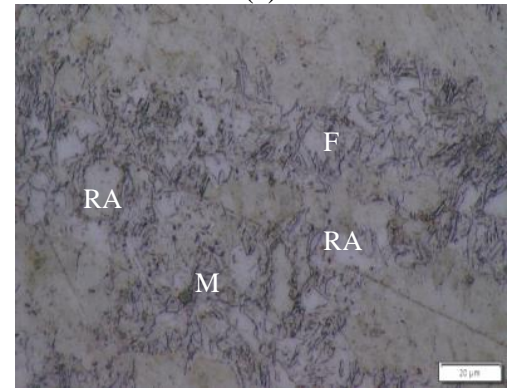

(b)

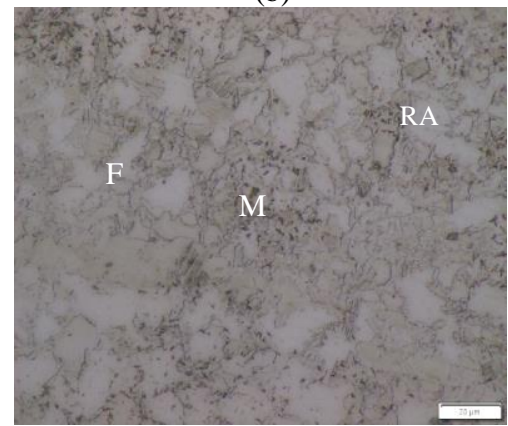

(c)

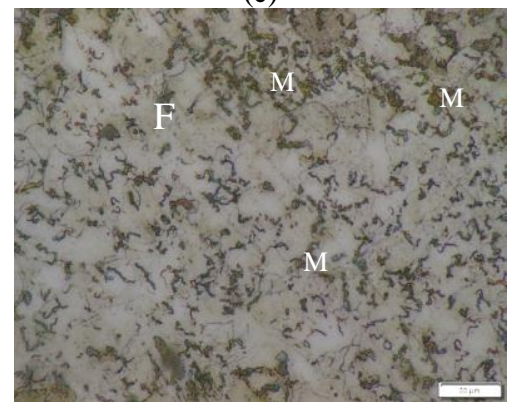

(d)

Gambar 3. Struktur mikro pada material (a) 0,42, (b) 1, (c) 2, dan (d) 3 \%berat nikel setelah proses penempaan dan perlakuan panas yang dilanjutkan dengan pendinginan air ( $\mathrm{M}=$ martensit, $\mathrm{RA}=$ austenit sisa, $\mathrm{F}=$ ferit $).$ Etsa Pikral

Bentuk bilah martensit sebagai dampak kandungan karbon rendah pada baja laterit yakni
0,13-0,19\%. Fasa martensit cenderung memiliki sifat keras dan kekuatan tinggi.

Selama perlakuan panas di atas temperatur $\mathrm{A}_{1}$, ada sebagian fasa austenit tidak bertransformasi setelah pendinginan cepat karena stabilitas termal yang tinggi. Bagian yang tidak bertransformasi menjadi martensit ini yang disebut austenit sisa. Seiring pertambahan kadar nikel, butir RA berukuran semakin besar yang ditunjukkan dengan luas area berwarna putih yang semakin besar. Struktur mikro ini sesuai dengan penelitian oleh Hasbi, dkk., [12] martensit merupakan fasa metastabil yang terbentuk dikarenakan kecepatan pendinginan dengan media air tidak memberikan waktu untuk karbon berdifusi menjadi ferit pada baja laterit. Selain itu, pada konsentrasi yang lebih tinggi (1$5 \%$ berat nikel), struktur mikro akhir mengarah pada peningkatan kandungan austenit sisa pada semua temperatur dan kandungan karbon [13]. Elemen paduan penstabil austenit berupa $\mathrm{C}, \mathrm{Mn}$, dan Ni memegang peranan penting pembentukan fasa RA.

Setelah perlakuan panas, perlit dari keadaan tempa berubah menjadi ferit, martensit, dan austenit yang tertahan. Butir austenit yang lebih kecil membentuk bilah martensit yang lebih halus setelah perlakuan panas, sedangkan martensit yang lebih panjang dalam baja laterit juga berarti ada butir yang lebih besar sebelum austenit diubah menjadi bainit dan martensit [11].

\subsection{Pengujian Kekerasan}

Pengujian kekerasan dilakukan untuk mengetahui korelasi kandungan fasa dengan kekerasan akibat pengaruh penambahan nikel pada modifikasi baja laterit A-588. Nilai kekerasan tersebut merupakan hasil rata-rata kekerasan dari 5 titik pada setiap sampel dengan menggunakan metode Brinell.

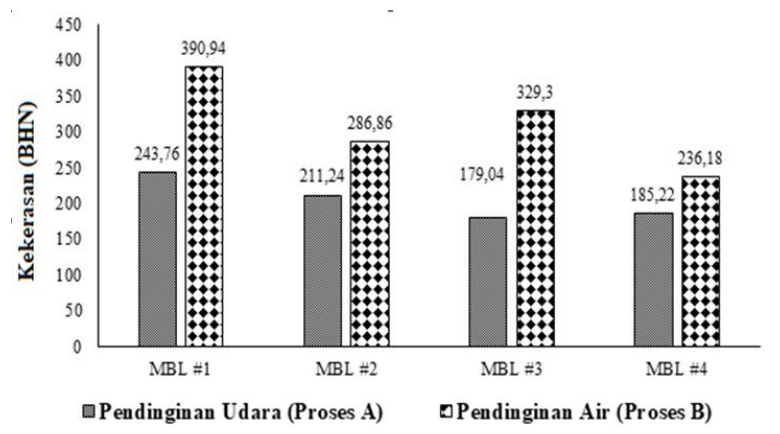

Gambar 4. Nilai kekerasan pada modifikasi baja laterit A588

Nilai kekerasan modifikasi baja laterit dengan penambahan kadar nikel setelah mengalami proses tempa panas dan perlakuan 
panas ditunjukkan pada Gambar 4. Secara umum, penambahan kadar nikel mempengaruhi pola nilai kekerasan secara signifikan pada kedua proses A dan B. Semakin tinggi kadar nikel (hingga $3 \%$ berat), semakin turun nilai kekerasannya. Pada MBL\#1 dengan 0,42 \% berat nikel, nilai kekerasan mencapai 243,76 BHN (sekitar 23 HRC) setelah tempa panas dan dilanjutkan normalizing. Sedangkan, pada MBL\#4 dengan 3 \%berat nikel, nilai kekerasannya menurun menjadi 185,22 BHN (sekitar 11 HRC). Penurunan ini disebakan oleh ukuran butir akhir semakin besar dan terbentuknya austenit tertahan. Nikel mempengaruhi energi penyusunan ulang sedemikian rupa pada saat transformasi fasa austenit sehingga lebih mudah bagi ferit untuk mengalami deformasi plastis pada temperatur rendah [11],[13].

Dengan kadar nikel yang sama, adanya proses perlakuan panas dengan pendinginan cepat akan memberikan nilai kekerasan yang lebih tinggi jika dibandingkan dengan proses A. Peningkatan kekerasan ini disebabkan oleh terbentuknya fasa akhir martensit sebagai matriks. Pada 0,42 \% berat nikel, variabel perlakuan panas memberikan nilai kekerasan sebesar 390,94 BHN (setara 42 HRC) dengan fasa akhir berupa ferit + perlit. Nilai ini jauh lebih tinggi jika dibandingkan dengan hasil tanpa perlakuan panas, yakni nilai kekerasan sebesar 236,18 BHN atau setara 22 HRC dengan fasa akhir berupa ferit + martensit + sisa austenit. Martensit berperan penting dalam meningkatkan nilai kekerasan akibat adanya tegangan dari karbon yang terperangkap ke dalam struktur kristal BCT (body centered tetragonal).

\subsection{Pengujian Tarik}

Pengujian tarik berfungsi untuk mengetahui pengaruh kadar nikel terhadap tingkat kekuatan dan keuletan baja laterit ketika dikenai beban statis. Hasil uji tarik ditunjukkan pada Gambar 5 dan 6.

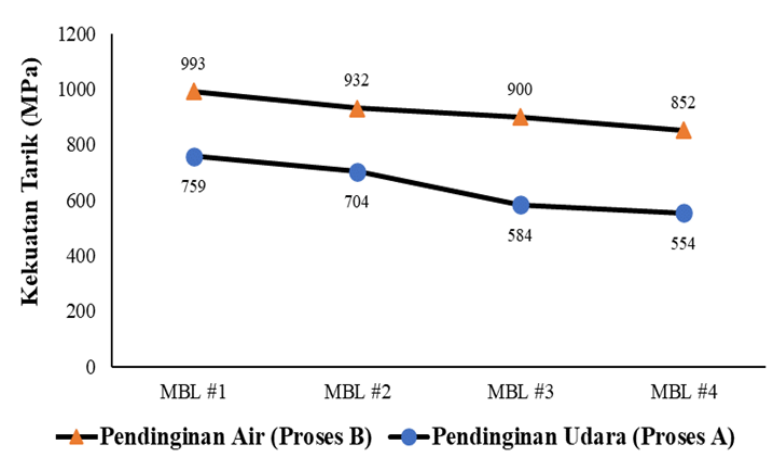

Gambar 5. Nilai kekuatan tarik maksimum (UTS) pada modifikasi baja laterit A-588
Secara umum, berdasarkan Gambar 5 dan 6, kekuatan tarik maksimum (ultimate tensile strength-UTS) setelah proses A dan B akan semakin menurun dan sifat keuletan semakin meningkat seiring dengan pertambahan $3 \%$ berat nikel. Pola penurunan nilai kekuatan tarik sesuai dengan pola penurunan nilai kekerasan untuk semua modifikasi baja laterit. Pada proses tempa panas dengan pendinginan udara, kekuatan tertinggi sebesar $759 \mathrm{MPa}$ diperoleh pada MBL\#1 dengan kandungan 0,42 \% berat nikel, dan kekuatan terendah sebesar $554 \mathrm{MPa}$ diperoleh pada MBL\#4 dengan kandungan 3 \% berat nikel. Sedangkan untuk proses B dengan pendinginan air, kekuatan tertinggi sebesar 993 MPa diperoleh pada MBL\#1 dengan kandungan 0,42 \%berat nikel, dan kekuatan terendah sebesar $852 \mathrm{MPa}$ diperoleh pada MBL\#4 dengan kandungan 3 \% berat nikel. Nikel dan krom cenderung menurunkan temperatur transformasi pembentukan martensit (Ms) sehingga jumlah martensit yang terbentuk lebih sedikit, kekuatan cenderung menurun, membentuk pola patahan quasi-cleavage dengan karakteristik campuran getas-ulet [14]. Selain itu, nikel mempengaruhi ukuran butir semakin besar sehingga memungkinkan deformasi plastis yang cukup besar akibat inisiasi fraktur ulet dari dominasi fasa ferit sebanyak $72-77 \% \mathrm{~V}_{\text {f. }}$ Nilai regangan dikonfirmasi pada Gambar 6.

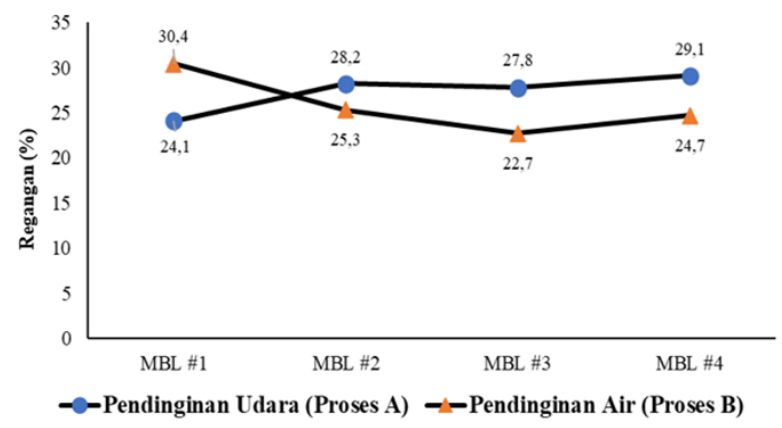

Gambar 6. Nilai regangan pada modifikasi baja laterit A-588

Pada modifikasi baja laterit, proses B (tempa dan dilanjutkan perlakuan panas dengan pendinginan air) menghasilkan kekuatan tarik lebih tinggi 130-150\% jika dibandingkan dengan proses A (tempa dan dilanjutkan perlakuan panas dengan pendinginan udara). Kadar nikel memberikan efek yang signifikan berbeda pada pola regangan. Pada proses A dengan pendinginan udara, nilai regangan cenderung naik namun tidak signifikan seiring dengan bertambahnya nikel. Sedangkan, pada proses B, nilai regangan cenderung menurun seiring dengan bertambahnya nikel. Hal ini disebabkan oleh deformasi menyebabkan transformasi 
austenit menjadi martensit. Nikel memfasilitasi distribusi slip lebih homogen di seluruh matriks dan proses rekristalisasi yang terjadi bersamaan dengan deformasi akibat tempa panas sehingga menghindari pengerasan regangan dan berakibat nilai keuletan naik [14].

Nilai kekuatan tarik maksimum dan regangan pada baja laterit A-588 melebihi nilai standar A588 komersil, yakni $485 \mathrm{MPa}$ dan $21 \%$ untuk jenis plat dengan ketebalan kurang dari $100 \mathrm{~mm}$ [8]. Oleh karena itu, baja laterit mampu menjadi alternatif bahan baku untuk diproses lebih lanjut menjadi baja tahan cuaca.

\subsection{Pengujian Korosi}

Kurva polarisasi modifikasi baja laterit A-588 dalam larutan $\mathrm{NaCl} 3,5$ \%berat setelah proses tempa dengan variasi proses perlakuan panas ditunjukkan oleh Gambar 7 dan 8. Gambar tersebut menunjukkan perubahan potensial korosi $\left(\mathrm{E}_{\text {corr }}\right)$ dan rapat arus korosi $\left(\mathrm{I}_{\text {corr }}\right)$ yang terjadi selama penambahan kadar nikel dan perbedaan perlakuan panas.

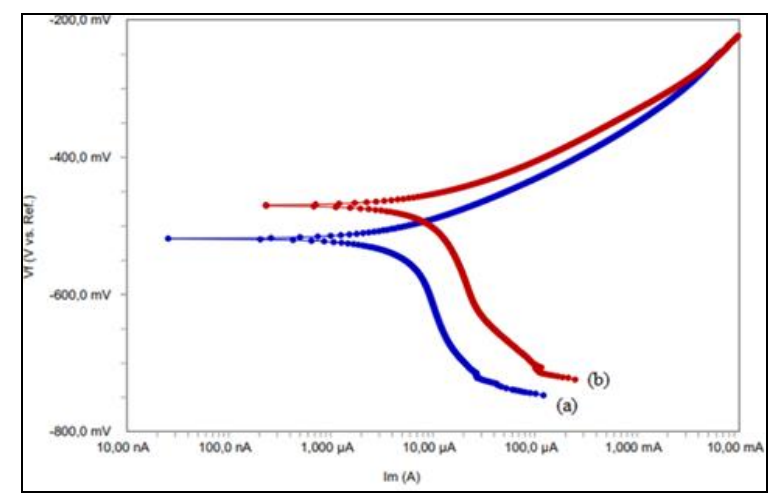

Gambar 7. Kurva polarisasi E versus Log I hasil tempa panas + pendinginan udara (a) 0,42 dan (b) $2 \%$ berat nikel

Gambar 7 menunjukkan perubahan kurva polarisasi yang terjadi pada modifikasi baja laterit hasil tempa panas dan pendinginan udara dengan kadar nikel $0,42 \%$ berat dan 2\%berat. Dengan $2 \%$ berat nikel dan bentuk butiran ferit agak kasar, kurva polarisasi bergeser ke kanan atas yang menunjukkan bahwa $\mathrm{I}_{\text {corr }}$ semakin besar dan $\mathrm{E}_{\text {corr }}$ semakin positif, yakni $-468,4 \mathrm{mV}$ dan $8,315 \times 10^{-6} \mathrm{~A} / \mathrm{cm}^{2}$. Hal ini menandakan bahwa pertambahan $2 \%$ berat nikel setelah tempa panas lebih mudah terkorosi akibat dominasi perubahan reaksi anodik dengan elektrolit $\mathrm{NaCl}$ 3,5\%volume dengan kondisi belum terbentuknya lapisan protektif antara $\mathrm{Cr}-\mathrm{Ni}-\mathrm{Cu}$ [5]. Selain itu, perbedaan karakteristik elektrokimia berkaitan dengan perbedaan struktur fasa dan ukuran butir. Semakin besar ukuran butir maka celah antar butir semakin besar sehingga semakin mudah terjadinya korosi galvanik, meskipun nikel merupakan salah satu unsur tahan korosi selain $\mathrm{Mn}, \mathrm{Cr}, \mathrm{Cu}$, dan Mo. Adanya perbedaan fasa yang signifikan menimbulkan kondisi lebih galvanik. Pada baja karbon rendah, struktur butiran ferit berbentuk kolom halus memanjang cenderung lebih stabil terhadap korosi $\mathrm{NaCl}$ dan struktur butir kasar menunjukkan perilaku aktif dalam elektrolit [15].

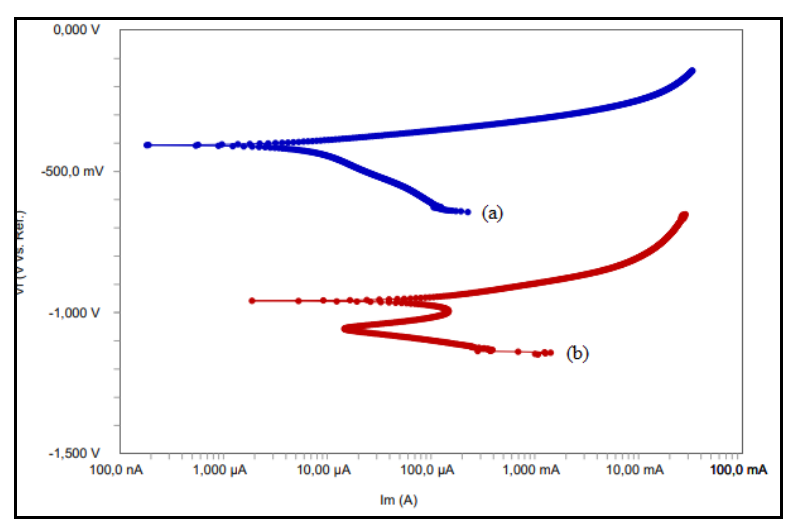

Gambar 8. Kurva polarisasi E versus Log I modifikasi baja laterit A-588 hasil tempa panas + pendinginan air dengan (a) 0,42 dan (b) $2 \%$ berat nikel

Gambar 8 menunjukkan perubahan kurva polarisasi yang terjadi pada modifikasi baja laterit hasil tempa panas yang dilanjutkan proses pemanasan dengan pendinginan air. Akibat penambahan $2 \%$ berat nikel, kurva polarisasi bergeser ke kanan bawah yang menunjukkan $\mathrm{I}_{\text {corr }}$ lebih besar dan $\mathrm{E}_{\text {corr }}$ semakin negatif, yakni -994 $\mathrm{mV}$ dan $32,78 \times 10^{-6} \mathrm{~A} / \mathrm{cm}^{2}$. Hal ini menandakan bahwa baja laterit dengan $2 \%$ berat nikel yang diproses tempa panas dan perlakuan panas fasa ganda menunjukkan lebih terkorosi dalam larutan 3,5 \%volume $\mathrm{NaCl}$. Hal ini berkolerasi dengan hasil pengamatan mikro yang menunjukkan fasa austenit sisa dan martensit sebagai fasa aktif. RA cenderung memiliki aktivitas energi lebih tinggi dan kadar karbon lebih tinggi dari fasa martensit sehingga efek peningkatan korosi galvanik dan disolusi selektif marginal terlihat sangat jelas dengan meningkatnya laju korosi [16].

Nilai laju korosi untuk masing-masing modifikasi baja laterit yang diuji pada larutan 3,5\%volume $\mathrm{NaCl}$ ditunjukkan pada Tabel 3 . Secara umum, penambahan $2 \%$ berat nikel pada modifikasi baja laterit A-588 memiliki $\mathrm{I}_{\text {corr }}$ dan laju korosi yang lebih tinggi, yakni 3,8 mpy untuk proses A, dan 14,98 mpy untuk proses B. Selain itu, proses kombinasi tempa panas dan perlakuan panas memberikan efek signifikan terhadap perubahan polarisasi. Dengan kadar nikel sama, perlakuan panas dengan pendinginan air memberikan laju korosi lebih tinggi. Hal ini disebabkan oleh perbedaan fasa akhir yang terkandung dalam baja laterit. 
Jika dibandingkan dengan A-588 komersil, baja laterit A-588 setelah proses tempa dan penambahan 2 \% berat nikel memiliki ketahanan korosi lebih tinggi. ASTM A-588 komersil tanpa penambahan lapisan cat memiliki nilai $\mathrm{E}_{\text {corr }}$ dan $\mathrm{I}_{\text {corr }}$ sebesar $-693 \mathrm{mV}$ dan $85 \mu \mathrm{m} / \mathrm{cm}^{2}$ jika terpapar dengan 3,5 \%berat $\mathrm{NaCl}$ [17]. Laju korosi imersi lebih tinggi dibandingkan dengan laju korosi atmosferik

Tabel 3. Parameter korosi pada modifikasi baja laterit A-588 dalam larutan 3,5\%volume $\mathrm{NaCl}$

\begin{tabular}{lcccc}
\hline \multirow{2}{*}{ Properties } & \multicolumn{2}{c}{$\begin{array}{c}\text { Proses A } \\
\text { (tempa panas + } \\
\text { pendinginan } \\
\text { udara) }\end{array}$} & \multicolumn{2}{c}{$\begin{array}{c}\text { Proses B } \\
\text { (tempa panas + } \\
\text { pendinginan air) }\end{array}$} \\
\cline { 2 - 5 } & $\begin{array}{c}\mathbf{0 , 4 2 \%} \\
\mathbf{N i}\end{array}$ & $\mathbf{2 \%} \mathbf{~ N i}$ & $\begin{array}{c}\mathbf{0 , 4 2 \%} \\
\mathbf{N i}\end{array}$ & $\mathbf{2 \%} \mathbf{~ N i}$ \\
\hline $\begin{array}{l}\text { Beta } \\
\left(10^{-3} \mathrm{~V} / \text { decade) }\right.\end{array}$ & 66,37 & 65,32 & 40,74 & 173,7 \\
$\begin{array}{l}\text { Potensial } \\
\text { korosi (mV) }\end{array}$ & $-515,5$ & $-468,4$ & $-405,6$ & $-994,0$ \\
$\begin{array}{l}\text { Rapat arus } \\
\text { korosi } \\
\left(10^{-6} \mathrm{~A} / \mathrm{cm}^{2}\right)\end{array}$ & 3,714 & 8,315 & 4,549 & 32,78 \\
$\begin{array}{l}\text { Laju korosi } \\
(\mathrm{mpy})\end{array}$ & 1,697 & 3,800 & 2,078 & 14,98 \\
\hline
\end{tabular}

\section{KeSIMPUlan}

Proses TMCP (thermo mechanical control process) berupa kombinasi penempaan panas dengan perlakuan panas diterapkan pada baja laterit A-588 yang dimodifikasi kandungan nikelnya. Kadar nikel mempengaruhi ukuran butir fasa serta fraksi fasa ferit-perlit pada tempa panas dilanjutkan pendinginan udara. Dengan 3 \% berat nikel, ukuran butir ferit-perlit yang terbentuk semakin besar yakni $\pm 0,1 \mathrm{~mm}$ (ASTM $\mathrm{G}$ nomor 3,7), sehingga kekerasan dan kekuatan menjadi semakin turun hingga 185,22 BHN dan $554 \mathrm{MPa}$, serta regangan semakin meningkat sebesar 29,1\%. Perbedaan fasa akhir menimbulkan kondisi lebih galvanik sehingga baja laterit lebih terkorosi dengan laju korosi sebesar 3,8 mpy. Pada baja paduan rendah, butiran ferit berbentuk kolom halus cenderung lebih tahan terhadap korosi $\mathrm{NaCl}$, sedangkan butiran kasar menunjukkan perilaku lebih aktif. Pada baja laterit setelah proses tempa panas dan perlakuan panas dengan pendinginan air, 3 \% berat nikel menyebabkan terbentuknya fasa dislokasi bilah martensit + ferit + austenit sisa sehingga kekerasan, kekuatan, dan regangan menurun hingga 236,18 $\mathrm{BHN}, 852 \mathrm{MPa}$, dan $24,7 \%$. Fasa austenit sisa memiliki efek merusak pada sifat mekanis dan sifat korosi.

Secara umum, tujuan pembentukan baja tahan cuaca dari baja laterit A-588 belum optimal dalam hal sifat mekanik dan ketahanan korosi. Oleh karena itu, diperlukan penelitian lebih lanjut untuk menganalisis parameter lainnya seperti kadar nikel lebih tinggi, temperatur pemanasan pada proses perlakuan panas, serta proses termomekanikal lainnya.

\section{UCAPAN TERIMA KASIH}

Penulis mengucapkan terimakasih kepada kelompok penelitian Baja Tahan Cuaca. Penelitian ini didanai oleh DIPA Pusat Penelitian Metalurgi dan Material pada tahun 2019.

\section{Daftar Pustaka}

[1] M. Morcillo, I. Díaz, B. Chico, H. Cano, and D. de la Fuente, "Weathering steels: from empirical development to scientific design. A review," Corros. Sci., vol. 83, pp. 6-31, 2014. Doi: 10.1016/j.corsci.2014.03.006.

[2] V. Urban, V. Krivy, and K. Kreislova, "The development of corrosion processes on weathering steel bridges," Procedia Eng., vol. 114, pp. 546-554, 2015. Doi: 10.1016/j.proeng.2015.08.104.

[3] M. Morcillo, I. Díaz, H. Cano, B. Chico, and D. de la Fuente, "Atmospheric corrosion of weathering steels. Overview for engineers. Part I: Basic concepts," Constr. Build. Mater., vol. 213, pp. 723737, 2019.2 Doi: 10.1016/j.conbuildmat.2019.03.334.

[4] K. Zacek, Ondrej;Liska, Miroslav;Kreislova, "Development of new structural weathering steels," Metals (Basel)., vol. 19, no. 21, pp. 1-12, 2009.

[5] X. M. Xiao, Y. Peng, C. Y. Ma, and Z. L. Tian, "Effects of alloy element and microstructure on corrosion resistant property of deposited metals of weathering steel," J. Iron Steel Res. Int., vol. 23, no. 2, pp. 171-177, 2016. Doi: 10.1016/S1006-706X(16)30030-9.

[6] Y. Zhou, J. Chen, Y. Xu, and Z. Liu, "Effects of $\mathrm{Cr}, \mathrm{Ni}$ and $\mathrm{Cu}$ on the corrosion behavior of low carbon microalloying steel in a Cl- containing environment," $J$. Mater. Sci. Technol., vol. 29, no. 2, pp. 168-174, 2013. Doi: 10.1016/j.jmst.2012.12.013.

[7] X. Cheng, Z. Jin, M. Liu, and X. Li, "Optimizing the nickel content in weathering steels to enhance their corrosion resistance in acidic atmospheres," Corros. Sci., vol. 115, pp. 135-142, $2017 . \quad$ Doi: 10.1016/j.corsci.2016.11.016.

[8] A. International, "Standard specification 
for high-strength low-alloy structural steel with $50 \mathrm{ksi}$ [345 MPa] minimum yield point to 4 in $[100 \mathrm{~mm}]$ thick 1 ," West Conshohocken, 1998.

[9] M. Zhan, Z. Sun, and H. Yang, "5.20 modeling of hot forging," in Comprehensive Materials Processing, vol. 5: Casting, J. McGeough, Ed. New York: Elsevier, 2014, pp. 441-493.

[10] M. A. Irshad, "The effect of prior austenite grain size on the machinability of a pre-hardened mold steel," Master's degree Diss., p. 77, 2011.

[11] F. Zhang, Y. Yang, Q. Shan, Z. Li, J. Bi, and R. Zhou, "Microstructure evolution and mechanical properties of $0.4 \mathrm{C}-\mathrm{Si}-\mathrm{Mn}$ $\mathrm{Cr}$ steel during high temperature deformation," Materials (Basel)., vol. 13, no. 1, 2020. Doi: 10.3390/ma13010172.

[12] M. Y.. Hasbi, T. B. Romijarso, P. A. Paristiawan, "Pengaruh kecepatan pendinginan baja fasa ganda $\mathrm{Fe}-\mathrm{Ni}$ dan nilai kekerasan," J. Teknol. Bahan dan Barang Tek., vol. 10, no. 2, pp. 84-91, 2020. Doi: 10.37209/jtbbt.

[13] E. Keehan, L. Karlsson, and H. O. Andren, "Influence of carbon, manganese and nickel on microstructure and properties of strong steel weld metals: Part 1 - Effect of nickel content," Sci. Technol. Weld. Join., vol. 11, no. 1, pp. 1-8, 2006. Doi: 10.1179/174329306X77830.

[14] C. G. Norwood, "The effect of nickel content on the mechanical properties and microstructure of a high toughness secondary hardening steel," Carnegie Mellon University (Thesis), Pittsburgh, 2016.

[15] H. Zhang, C. Wang, B. Xue, and J. Luo, "Effect of grain size on the corrosion resistance of low carbon steel," Mater. Sci. Forum, vol. 984, pp. 43-50, 2020. Doi: 10.4028/www.scientific.net/msf.984.43.

[16] Neetu, P. K. Katiyar, S. Sangal, and K. Mondal, "Effect of various phase fraction of bainite, intercritical ferrite, retained austenite and pearlite on the corrosion behavior of multiphase steels," Corros. Sci., vol. 178, p. 109043, 2021. Doi: 10.1016/j.corsci.2020.109043.

[17] Q. A. . Kaseasbeh, "Electrochemical investigation of corrosion resistance of North Dakota State University," North Dakota State Univ., no. November, 2015. 
42 | Metalurgi, V. 36.1.2021, P-ISSN 0126-3188, E-ISSN 2443-3926/ 33-42 